\title{
THE IMPACT OF OBSTETRICIAN/GYNECOLOGIST HOSPITALISTS ON NEONATAL QUALITY OF CARE IN SARDJITO GENERAL HOSPITAL YOGYAKARTA, INDONESIA: A RETROSPECTIVE COHORT STUDY
}

\author{
Eugenius Phyowai Ganap ${ }^{1}$, Mohammad Hakimi², Soerjo Hadijono ${ }^{3}$, Ova Emilia ${ }^{4}$
}

\begin{abstract}
Background : The hospitalist model in obstetric care which was introduced over the last decades now has an important role in care delivery management with the potential positive impact on neonatal outcomes. Methods : This research design was retrospective cohort. Participants included is the patient in the time before and after implementation of obstetrician/gynecologist full-hospitalist policy during October 2013 until September 2014. The outcome measured were mean response time, APGAR score at 5 minutes, , NICU admission. Univariate and multivariable analyses was conducted to evaluate and determine the factor which significantly contribute to neonatal outcomes.

Results and Discussion: We included total 71 patients (37 on-call obstetrician group and 34 full-time hospitalist group). Univariate analysis indicated mean response time was significantly differ in full-time hospitalist group when compared to the on-call obstetrician group $(65,3 \pm 25,89$ vs. $84 \pm 22,29$ mins; $p=$ $0,002)$. Implementation of full-time hospitalist did not impact the NICU admission and APGAR score at 5 minutes.
\end{abstract}

Conclusion : Implementation of full-time hospitalist model is not affecting neonatal outcomes.

Keywords : Infant and Maternal Mortality, Obtericians / Gynecologist Hospitalist, Labor and Delivery, Maternal and Neonatal Care, ICU Response Time.

\begin{abstract}
ABSTRAK
Latar Belakang: Diberlakukannya dokter spesialis jaga onsite yang diperkenalkan selama beberapa dekade terakhir memberikan peranan penting dalam manajemen persalinan dengan dampak yang cukup positip pada luaran neonatus.

Metode: Desain dari penelitian ini adalah kohor retrospektif. Subyek adalah pasien-pasien yang terdaftar sebelum maupun sesudah implementasi dari kebijakan jaga on site dokter spesialis di RSUP dr Sardjito selama periode Oktober 2013 sampai dengan September 2014. Luaran yang diukur adalah response time, APGAR score menit ke-5, dan kebutuhan akan NICU. Analisis univariat dan multivariate dilakukan untuk mengevaluasi dan menentukan faktor yang secara signifikan berkontribusi pada luaran neonatus.

Hasil dan Pembahasan: Kami mengikutkan total 71 pasien (37 pasien pada group dokter spesialis jaga oncall dan 34 pasien pada group dokter spesialis jaga on-site). Pada analisis univariat menunjukan rata-rata response time berbeda secara signifikan pada group jaga on-site dibandingkan group jaga on-call $(65,3 \pm$ 25,89 vs. $84 \pm 22,29$ menit; $p=0,002$ ). Implementasi jaga on-site tidak berdampak pada pada kebutuhan akan NICU dan APGAR score pada menit ke-5.

Kesimpulan: Implementasi dari model jaga on-site tidak mempengaruhi luaran neonatus.
\end{abstract}

Kata Kunci : mortalitas dan mordibilitas ibu \& anak, dokter jaga onsite, perawatan neonatus, waktu tanggap

Departemen Obstretri \& Ginekologi Fakultas Kedokteran UGM/RSUP Dr. Sardjito 


\section{BACKGROUND}

Indonesia which had many significant achievements on societal, political, and economic development, still struggles with high rate of maternal death. Descriptive data from 2012 Indonesia Demographic and Health Survey (IDHS) has shown that, maternal mortality ratio increased significantly from 228 per 100.000 live births in 2007 became 359 per 100.000 live births in $2012 .^{1,2}$ World Health Organization (WHO) estimated there were 8.800 mothers died from 4.5 million live births in 2013. ${ }^{3}$ The direct obstetric causes still the major causes of all deaths. Obstetric complication such as hemorrhage, hypertensive disorders, and sepsis accounted for $80 \%$, and all other direct causes of death is about $20 \%$. ${ }^{4}$

The conceptual framework developed by Thaddeus and Maine ${ }^{5}$ identify "three delays model" as significant contributors in maternal deaths, which are ${ }^{1}$ delay in deciding to seek care, ${ }^{2}$ delay in identifying and reaching health facility, and ${ }^{3}$ delay in receiving adequate and appropriate treatment. Delay in accessing maternal health care is still being the barrier in Indonesia, include limited availability of health staff and limited infrastructure or facilities. ${ }^{6}$

In order to reduce maternal mortality rate, it requires good medical strategies, one of strategy is to optimaliz the provision of emergency maternal care. The key indicator in emergency maternal care provision is emergency response time. Response time is interval between call receipt, arrival on scene and provision of service for the patient. The availability of obstetrician/ gynecologist hospitalists and also health facilities provide variety in results toward emergency response time.

One of the problem faced by Sardjito General Hospital as tertiary referral hospital for maternal care in Yogyakarta Special Region is limited facilities which has implication on the delay in preparation of surgery (i.e. Caesarean Delivery). The emerging model was introduced over the last decades, which called "hospitalist medicine" or "hospitalist". Hospitalist as described by Wacther and Goldman in New England Journal of Medicine article "The emerging role of 'Hospitalists' in the American Health Care System" is a physician whose primary focus is in the inpatient medical care. ${ }^{7}$ Specifically, obstetrician/gynecologist (ob/ gyn) hospitalist is a 24-hour a day/7-day a week physician who assists or who is employed by the hospital to manage laboring patients, obstetric triage and emergencies. 8 Since April 2014, Sardjito General Hospital have already enforced implementation of obstetrician/gynecologist hospitalists with the goal to shorten emergency response time for surgery.

The purpose of this study is to explore the impact of obstetrician/gynecologist hospitalists on maternal and neonatal quality of care, to examine the factors associated with emergency response time and to compare emergency response time between before and after implementation of obstetrician/gynecologist hospitalists policy.

\section{METHOD}

\section{Study design, site and sampling methods}

This is a retrospective cohort study conducted in Emergency Department of Sardjito General Hospital, Yogyakarta Special Region Province, Indonesia in the period of October 2013 September 2014. With a purposive sampling technique, 71 samples were obtained from the population who received crash emergency caesarean section.

\section{Participants}

The population is the pregnant women patients in Emergency Department of Sardjito General Hospital and who have to received emergency caesarean section in the period of study. The participants included is the patient in the time before and after implementation of obstetrician/gynecologist hospitalists policy. Emergency caesarean sectons were defined as 
unscheduled caesarean deliveries performed before or during labour and designated as such in the operative report by the surgeon.

\section{Data Collection and analysis}

Information on demographic characteristic, gestational ages, parity status, labor course and indication for caesarean section were collected. Emergency response time or decision-to-delivery interval, defined as the duration between the time the decision was made to the time the baby was delivered by emergency caesarean section (in minutes) was recorded for each patient.

The primary outcomes measured in this study for neonatal outcomes included in this study were birthweight neonatal intensive care unit (NICU) admission and asphyxia incidence according to APGAR Score.

Statistical analysis was performed using SPSS 16 (SPSS Inc., Chicago, Illinois, USA). Demographic and pregnancy characteristics in the 'before or on-call obstetrician' and 'after or full-time hospitalist' implementation of policy were compared. A normality test was conducted for continuous data with Shapiro-Wilk test $(p>$ 0,05 indicated normal distribution) before each analysis. For normally distributed data, Student's t-test was performed to compare data between two groups ('Before' and 'After'), and for nonnormally distributed data the Mann-Whitney test was performed. Categorical variables were compared with bivariate analysis using ChiSquare test. Multivariate analysis was performed to explore the factors which has significant association with emergency response time. Tests with $p<0,05$ were considered statistically significant.

The Medical and Health Research Ethics Committee Faculty of Medicine Universitas Gadjah Mada and Dr. Sardjito Hospital approved the study protocol and released the ethical clearance (No. KE/FK/371/EC).

\section{RESULTS}

\section{Characteristics of the study subjects}

During the time periods described six months before and after implementation of the policy (October 2013 - March 2014 and April 2014 - September 2014), data were reviewed on 37 cases and 34 cases respectively. Demographic and clinical variables are compared between two groups in Table 1.

Table 1 The characteristics of subjects grouped based on before and after implementation of hospitalist policy

\begin{tabular}{lccc}
\hline \multicolumn{1}{c}{ Variables } & $\begin{array}{c}\text { On-call Obstetrician } \\
(\mathrm{n}=30)\end{array}$ & $\begin{array}{c}\text { Full-time Hospitalist } \\
(\mathrm{n}=41)\end{array}$ & P value \\
\hline $\begin{array}{l}\text { Mean response time, (mins) } \\
\text { Gestational age, } \mathrm{n}(\%)\end{array}$ & $84 \pm 22,29$ & $65,3 \pm 25,89$ & 0,002 \\
$\quad<37$ weeks & $8(11,3)$ & $21(29,6)$ & 0,03 \\
$\quad$ 37 weeks & $22(31,0)$ & $20(28,2)$ & \\
Parital status, $\mathrm{n}(\%)$ & & & \\
$\quad<3$ & $25(35,2)$ & $28(39,4)$ & \\
$>3$ & $5(7,0)$ & $13(18,3)$ & \\
Birthweight, (grams) & & & \\
$\quad<2500$ & $14(19,7)$ & $23(32,4)$ & \\
$\quad \geq 2500$ & $16(22,5)$ & $18(25,4)$ & \\
$\quad$ APGAR Score & & & \\
$\quad<7$ & $18(25,4)$ & $27(38,0)$ & 0,61 \\
$\geq 7$ & $12(16,9)$ & $14(19,7)$ & \\
\hline
\end{tabular}

Neonates in full-time hospitalist group were delivered significantly more preterm $(p=0,03)$ than on-call obstetrician group. 
Neonates in full-time hospitalist group were delivered significantly more preterm $(p=0,03)$ than on-call obstetrician group.

\section{Impact on neonatal outcomes}

We evaluated the impact of this policy on neonatal outcomes included birthweight at delivery, NICU admission, and asphyxia incidence according to APGAR score. The neonatal outcomes between two groups as shown in Table 2.

Table 2 Neonatal outcomes between two groups

\begin{tabular}{lcccc}
\hline Variables & $\begin{array}{c}\text { On-call } \\
\text { Obstetrician } \\
(\mathrm{n}=30)\end{array}$ & $\begin{array}{c}\text { Full-time } \\
\text { Hospitalist } \\
(\mathrm{n}=41)\end{array}$ & $\begin{array}{c}\mathrm{RR} \\
(95 \% \mathrm{Cl})\end{array}$ & P value \\
\hline $\begin{array}{l}\text { Birthweight, } \mathrm{n}(\%) \\
<2500 \mathrm{gr}\end{array}$ & $14(19,7)$ & $23(32,4)$ & 0,62 & 0,72 \\
$\quad$ 2500 gr & $16(22,5)$ & $18(25,4)$ & $(0,26-1,76)$ & \\
\hline NICU admission $\mathrm{n}(\%)$ & $14(19,7)$ & $18(25,4)$ & 1,18 & 0,81 \\
$\quad$ Yes & $16(22,5)$ & $23(32,4)$ & $(0,43-2,88)$ & \\
$\quad$ No & $18(25,4)$ & $27(38,0)$ & 0,78 & 0,61 \\
$\begin{array}{l}\text { APGAR Score } \mathrm{n}(\%) \\
\quad>7\end{array}$ & $12(16,9)$ & $14(19,7)$ & $(0,29-2,06)$ & \\
$\geq 7$ & & &
\end{tabular}

\section{Factors associated with neonatal outcomes}

Other factors were included in analysis to measure the association with neonatal outcomes such as parital status, gestational ages, readiness of operating theatre and anesthetist

Table 3 Multivariable analysis among variables that associated with neonatal outcome : NICU admission

\begin{tabular}{lccc}
\hline \multicolumn{1}{c}{ Variables } & OR & Cl (95\%) & p value \\
\hline Birthweight $<2500$ grams & 1,97 & $0.15-2.25$ & 0.21 \\
Gestational age $<37$ weeks & 1,94 & $0.66-5.66$ & 0.22 \\
Readiness of anesthetist & 0.37 & $0.67-5.85$ & 0.28 \\
Readiness of operating theatre & 3,49 & $0.54-22,49$ & 0.18 \\
\hline
\end{tabular}

\section{DISCUSSION}

The implementation of full-time hospitalists in this study shows significantly improvement of obstetric care delivery. This study assesses the impact of hospitalists on neonatal outcomes using some parameters and patients. We found hospitalists could reduce response time significantly. Reduction in response time could improved clinical management Previous study shows the decision to incision interval of more 
than 30 minutes associated with higher incidence of adverse neonatal outcome, such as admission to the neonatal intensive care unit. ${ }^{9}$

Our study results as shown in Table 1, the mean response time is significantly quicker in full-time hospitalists group compared to another group $(65,3+25,89$ mins vs. $84+22,29$ mins; $p=0.002)$. Although the mean response time significantly improved, this results are still above the expected response time as recommended by RCOG/NICE guidelines. The National Institute for Health and Clinical Excellence (NICE) recommends delivery should be accomplished within 30 minutes where possible in cases of confirmed or suspected fetal compromised. ${ }^{10}$ Interestingly, Sibuea (2007) found that the incidence of severe asphyxia and neonatal mortality in emergency SC is higher than elective SC and vaginal delivery. ${ }^{11}$

Our findings showed that several factors associated with response time improvement in this research including the implementation of fulltime hospitalists itself and readiness of operating theatre. The finding that implementation of full-time hospitalists are more likely to have quicker response time in obstetric emergency management. This may be explained by the concept of full-time hospitalists in which provide 24-hour a day in-house obstetrician. This concept is proposed to improve patient safety, reduce response time, and make more efficient clinical management. ${ }^{12}$ The hospital factor that also evaluate in this study is readiness of operating theatre which has significant contribution to response time improvement. OB/GYN hospitalist program cost in Sardjito General hospital during the implementation of the policy at least 11.25 million per day or 337.5 million rupiahs per month.

A key concept of OB/GYN hospitalist model is the 24-hour in-hospital coverage to improve neonatal outcomes. In our study we have performed multivariate analysis to find the association some variables to neonatal outcomes. The result was no significant difference in neonatal outcomes between on-call obstetrician and full-time hospitalists. Previous report also shows the same results with our study. ${ }^{13}$ In contrast, Goffman and colleagues with a program similar to laborist model showed a significant reduction (approx. 42\%) in maternal and neonatal adverse events. ${ }^{14}$

\section{CONCLUSION}

Implementation of full-time hospitalist model is associated with a significant improvement of response time in emergency obstetric care without affecting neonatal outcomes.

\section{REFERENCES}

1. Badan Pusat Statistik-Statistics Indonesia (BPS) National Family Planning Coordinating Board Ministry of Health ORC Macro: Indonesia Demographic and Health Survey 2007. Calverton, Maryland: BPS and ORC Macro. 2008. https://dhsprogram.com/pubs/pdf/FR218/ FR218\%5B27August2010\%5D.pdf

2. Statistics Indonesia (Badan Pusat StatistikBPS), National Population and Family Planning Board (BKKBN), and Kementerian Kesehatan (Kemenkes-MOH), and ICF International. 2013. Indonesia Demographic and Health Survey 2012. Jakarta, Indonesia: BPS, BKKBN, Kemenkes, and ICF International. https://dhsprogram.com/pubs/pdf/ FR275/FR275.pdf

3. WHO, UNICEF, UNFPA and The World Bank estimates. Trends in maternal mortality: 1990 to 2013. http://apps.who.int/iris/bitstream/ 10665/ 112682/2/9789241507226_eng.pdf

4. Putra, M.P., Yudha, editors. Menkes: Angka Kematian Ibu Melahirkan Masih Tinggi [Internet]. Jakarta: Republika;2013 [cited 2013 May 5]. Available from: http://www.republika.co.id/berita/ nasional/daerah/13/02/16/mi9ugy-menkes-angkakematian-ibu-melahirkan-masih-tinggi

5. Thaddeus S, Maine D. Too far to walk : maternal mortality in context. Soc Scie Med. 1994 Apr; 38(8):m 1091-110. 
6. Widawati. Faktor yang mempengaruhi pola pemilihan penolong persalinan di kecamatan bojongloa kidul, kota bandung tahun 2007 [thesis]. Universitas Indonesia; 2008.

7. Wachter RM, Goldman L. The emerging role of "hospitalists" in the American health care system. N Engl J Med 1996; 335:514-7.

8. Olson R, Garite TJ, Fishman A, Andress IF. Obstetrician/gynecologist hospitalists: can we improve safety and outcomes for patients and hospitals and improve lifestyle for physicians?. Am J Obstet Gynecol 2012; 81-6.

9. Chauhan SP, Roach $\mathrm{H}$, Naef RW, et al. Cesarean section for suspected fetal distress. Does the decision-incision time make a difference? J Reprod Med 1997;42:347-52

10. National Institute for Health and Care Excellence. Clinical Guideline : Caesarean Section. London, UK : NICE 2011.
11. Sibuea H. 2007. Manajemen Seksio Sesarea Emergensi: Masalah dan Tantangan. Pidato pengukuhan Guru Besar Bidang Kebidanan dan Penyakit Kandungan Universitas Sumatera Utara.

12. Olson R, Thomas JG, Fishman A. et al. Obstetrician/ gynecologist hospitalists: can we improve safety and outcomes for patients and hospitals and improve lifestyle for physicians. American Journal of Obstetrics and Gynecology 2012. 81-86

13. Srinavas SK, Small DS et al. Evaluating the impact of the laborist model of obstetric care on maternal and neonatal outcomes. American Journal of Obstetrics and Gynecology (2016), doi: 10.1016/j. ajog.2016.08.007

14. Goffman D, Broadman M, Arnold AJ, et al. Improved obstetric safety through programmatic collaboration. J Healthc Risk Manag 2014;33(3):1422 